\title{
BERPIKIR ANALITIK MAHASISWA DALAM MENGONSTRUKSI BUKTI SECARA SINTAKSIS
}

\author{
Puguh Darmawan \\ Pendidikan Matematika-Pascasarjana Universitas Negeri Malang \\ e-mail: puguhdarmawan212@gmail.com
}

\begin{abstract}
Abstrak
Fenomena menunjukan kegagalan mahasiswa dalam mengonstruksi bukti secara sintaksis dikarenakan mahasiswa tidak berpikir analitik. Kemampuan mahasiswa dalam mengonstruksi bukti sangat menentukan keberhasilannya mempelajari matematika tingkat lanjut, sehingga penelitian untuk mengungkap fenomena ini penting dilakukan. Penelitian ini bertujuan mendeskripsikan berpikir analitik mahasiswa dalam mengonstruksi bukti secara sintaksis. Untuk mengetahui berpikir analitik mahasiswa, peneliti memberikan masalah pembuktian kepada sekelompok mahasiswa yang telah menempuh Geometri. Dilihat dari keanalitikan jawaban mahasiswa, peneliti menemukan tiga kategori berpikir, yaitu; (1) analitik, (2) semi analitik, dan (3) pre analitik. Berpikir analitik ditandai oleh adanya konstruksi bukti yang jelas, kejelasan algoritma, keruntutuan penalaran, penggunaan simbol secara tepat, setiap pernyataan dilandasi oleh alasan yang tepat dan langkah yang efektif. Berpikir semi analitik ditandai oleh adanya "elemen pengganggu" pemutus rantai implikasi. Berpikir pre analitik ditandai oleh penggunaan gambar sebagai bukti.
\end{abstract}

Kata Kunci : Berpikir Analitik, Bukti, Sintaksis.

\section{PENDAHULUAN}

Matematika terbentuk dari pengalaman manusia dalam dunianya secara empiris. Pengalaman itu diproses secara rasional dan analitis dengan penalaran di dalam struktur kognitif sehingga sampai terbentuk konsep-konsep matematika (Ruseffendi, 1980). Windsor (2008) mengemukakan bahwa mempelajari matematika sama halnya dengan berpikir tentang pola-pola, komunikasi mengenai pola-pola itu, atau belajar untuk bekerja dengan pola-pola itu. Mempelajari matematika berarti belajar tentang sesuatu yang abstrak dan memuat pengertian-pengertian yang dituangkan ke dalam simbol-simbol atau gambar-gambar. Oleh karena itu didalam mempelajarinya diperlukan keterampilan berpikir dan bernalar tinggi pada diri mahasiswa.

Salah satu komponen penting dalam matematika yang memerlukan kemampuan berpikir tingkat tinggi dalam penyelesaiannya adalah bukti matematis. Bukti sangat 
fundamental dalam matematika (Varghese, 2009:3). Bukti menempati inti berpikir matematis dan bernalar secara deduktif (Healy \& Hoyles, 1998) karena bukti adalah penentu kebenaran klaim matematis (Hanna \& Barbeau, 2008:85). Bukti matematis adalah suatu demonstrasi yang menyatakan kebenaran suatu pernyataan berdasarkan asumsi yang diberikan (Alcock \& Inglis, 2010:44). Kemampuan mahasiswa dalam pembuktian sangat penting bagi keberhasilan mereka dalam belajar matematika. Sebagaimana yang dinyatakan Chen (2008) yaitu kemampuan siswa dalam menyusun bukti yang valid sangat penting untuk keberhasilan mereka dalam matematika, ketidakmampuan siswa untuk menyusun bukti sering menjadi kendala utama mereka dalam menguasai topik topik lanjutan dalam matematika.

Dalam menyelesaikan masalah pembuktian mahasiswa perlu memahami kondisi yang ada. Menurut Polya (dalam Orton, 1991:94) untuk memecahkan suatu masalah, termasuk masalah pembuktian diperlukan empat tahap yaitu (1) memahami masalah, (2) membuat rencana, (3) melaksanakan rencana, dan (4) melihat kembali. Menurut Musser \& Burger (1994:4) tahap-tahap pemecahan masalah Polya dapat dijabarkan kedalam beberapa poin. Pada tahap memahami masalah seseorang dihadapkan dengan beberapa pertanyaan, diantaranya adalah sebagai berikut (a) Apakah informasi yang tersedia cukup? (b) Apakah terdapat informasi tambahan?. Pada tahap membuat rencana seseorang dihadapkan dengan pertanyaan tentang pemilihan strategi yang tepat dalam memecahkan masalah. Setelah melalui dua tahap tersebut seseorang kemudian dapat melaksanakan strategi yang telah dipilih sampai masalah terpecahkan atau sampai suatu tindakan baru dianjurkan. Jadi berpikir analitik merupakan bagian yang harus dilakukan dalam pemecahan masalah pembuktian karena berpikir analitik merupakan; (1) kemampuan untuk meneliti dan mengurai fakta-fakta dan pemikiran menjadi kekuatan-kelemahan; dan (2) mengembangkan kapasitas untuk berpikir bijaksana, cerdas, menyelesaikan masalah, menganalisis data, mengingat dan menggunakan informasi (Amer, dkk, 2005). Parta (2016) juga menyatakan bahwa berpikir analitik digunakan dalam menyelesaikan soal non rutin (masalah).

Menurut Robbins (2011: 41), berpikir analitik adalah serentetan perilaku yang seragam, tetapi melibatkan unsur penyelidikan dan situasi lebih lanjut dengan hasil dan parameter yang kurang terdefinisi dengan baik. Berpikir analitik adalah berpikir tahap demi tahap untuk menyelesaikan masalah dalam rangka mengaitkan hubungan dan menjelaskan pengaruh antar variabel yang disertai dengan mempertimbangkan bukti-bukti yang ada, dengan tantangan situasi yang ambigu dan masalah yang kurang terstruktur lengkap atau informasi yang disampaikan kurang, sehingga mahasiswa bisa memilih informasi yang penting dan relevan berdasarkan masalah yang diajukan.

Montaku (2011) berpandangan bahwa berpikir analitik berarti berpikir dari peristiwa yang berurutan menjadi bagian-bagian masalah yang disajikan dengan alasan, prinsip, fungsi, kemampuan untuk menghubungkan isu-isu, kemampuan untuk menjawab masing-masing masalah dan melihat kembali masalah sebelumnya. Analisis dapat diklasifikasikan menjadi 3 bagian kecil; (1) analisis elemen yang dimaksudkan untuk mengklasifikasikan apa yang penting atau diperlukan atau yang paling berperan dan mana yang merupakan penyebab atau 
hasil, (2) analisis hubungan berarti pencarian untuk sub-hubungan cerita atau bukti dan bagaimana hal tersebut saling berhubungan, konsisten atau bertentangan, (3) analisis prinsipprinsip organisasi berarti mencari struktur sistem atau soal cerita dan tindakan yang berbeda untuk melihat bagaimana sistem tersebut berhubungan (Bloom dalam Montaku, 2012). Pandangan ini sesuai dengan berpikir analitik mahasiswa pada penelitian Parta (2016) dalam menyelesaikan persamaan garis lurus dengan gradien tak terdefinisi. Berpikir analitik dalam menyelesaikan masalah tampak bertahap pada empat bagian dari penyelesaian masalah. Keempat bagian itu diberi kode 1, 2, 3, dan 4 seperti gambar di bawah ini.

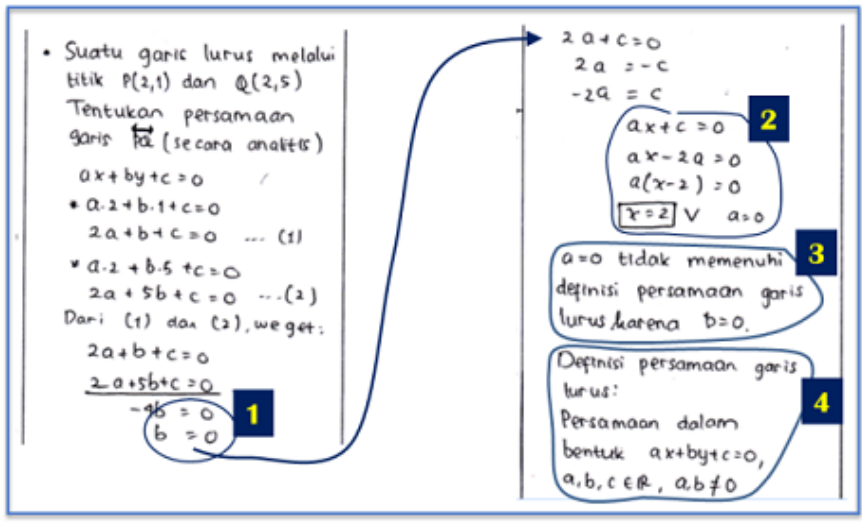

Gambar 1. Penyelesaian Bertahap

Dengan berpikir analitik, mahasiswa dapat merancang kerangka bukti, menggunakan definisi yang sesuai dan mempertimbangkan bukti-bukti yang ada untuk menurunkan pernyataan dengan menerapkan teorema yang ada dan aturan inferensi, hingga mencapai kesimpulan. Mahasiswa dapat melakukan itu tanpa mempertimbangkan bentuk/struktur dalam sistem representasi lain, seperti grafik, argumen informal, atau contoh prototipikal dari konsep-konsep matematika yang relevan dengan strategi sintaksis (Weber \& Alcock, 2004). Alcock \& Inglis (2008:115) mendefinisikan strategi sintaksis terjadi ketika seluruh proses pembuktian terjadi dalam dunia formal. Istilah berbeda dari strategi sintaksis adalah jalur formal (Pinto ,1998). Mahsiswa harus mampu berpikir formal dalam mengonstruksi bukti karena argumen yang dianggap sebagai bukti matematis, harus didasarkan pada aksioma dan definisi (Chazan, D \& Lueke, M. dalam Knuth, 2009). Akan tetapi pada kenyataannya masih banyak mahasiswa yang tidak mampu berpikir formal. Fakta ini ditemukan pada mahasiswa semester satu. Padahal kemampuan berpikir formal adalah salah satu unsur yang mempunyai peranan penting untuk memahami konsep, hukum dan prinsip-prinsip ilmu pengetahuan. Kemampuan seseorang untuk membuat analisis dan mengembangkan teori memerlukan kemampuan berpikir yang ada di dunia formal. Dunia formal yang berdasarkan pada aksioma berguna untuk membangun sistem, berdasarkan definisi untuk membuat konsep baru, dan berdasarkan bukti formal untuk membangun teori-teori yang koheren (Tall, 2009).

Kemampuan mahasiswa semester pertama dalam pembuktian tentu saja akan berpengaruh pada pembelajaran matakuliah lainnya yang sarat dengan pembuktian, seperti mata kuliah Analisis Real, Aljabar Abstrak, dan yang lainnya. Geometri adalah matakuliah di semester pertama yang memberikan kesempatan kepada mahasiswa untuk mengembangkan 
kemampuan berpikir analitik dalam mengonstruksi bukti. Kemampuan mahasiswa dalam mengonstruksi bukti pada matakuliah Geometri sangatlah penting sebagai dasar mempelajari bukti matematis lebih lanjut, khususnya pada materi kekongruenan segitiga, hal ini dikarenakan bagian paling luas dan sangat penting dalam Geometri adalah perhatian terhadap hubungan yang ada pada segitiga (Lewis,1968). Mulyati (1999) juga berpendapat bahwa segitiga memegang peranan yang sangat penting dalam mempelajari Geometri, karena semua poligon dapat dipartisi ke dalam daerah-daerah segitiga.

Dalam dokumen NCTM (2000: 124) tertulis "Pembuktian dirasakan sangat sulit bagi mahasiswa matematika tingkat sarjana". Penelitian menemukan bahwa masih banyak mahasiswa yang mengalami kesulitan dalam membuktikan Weber; (2001), Recio \& Godino; (2001), dan Selden \& Selden; (2003). Kesulitan ini dapat dipicu oleh berbagai hal. Weber (2001) menemukan bahwa penyebab awal kegagalan mahasiswa dalam membuktikan disebabkan oleh kurangnya pengetahuan strategik. Sementara Recio \& Godino (2001) menemukan bahwa kemampuan mahasiswa untuk menghasilkan bukti secara deduktif masih sangat terbatas. Selden \& Selden (dalam Weber, 2004) menyatakan bahwa mahasiswa tidak dapat menentukan apakah bukti yang dimaksud sah atau tidak. Weber (2004) menyatakan bahwa penelitian mengenai kemampuan mahasiswa dalam menyusun bukti lebih difokuskan pada bukti yang dihasilkan mahasiswa. Bukti dipilah ke dalam bukti yang valid dan tidak valid. Rasio antara bukti yang valid dan tidak valid digunakan sebagai alat ukur mengenai kemampuan menyusun bukti (Senk dalam Weber, 2004). Bukti yang tidak valid digunakan untuk mengklasifikasikan kesulitan mahasiswa dan untuk mengetahui konsepsi mahasiswa mengenai bukti (Selden \& Selden, 2003 dan Zazkis, dkk.,2003). Peneliti berpendapat bahwa untuk mengetahui kemampuan mahasiswa dalam mengonstruksi bukti tidak cukup dilihat dari bukti yang dihasilkan. Lebih dari itu, proses berpikir yang terjadi dalam menyusun bukti justru dapat memberi petunjuk yang lebih baik untuk mengetahui kemampuan mahasiswa dalam menyusun bukti formal.

Peneliti menemukan kegagalan mahasiswa dalam mengonstruksi bukti kongruensi segitiga secara sintaksis karena mahasiswa tidak berpikir analitik, hal itu nampak pada gambar di bawah ini.

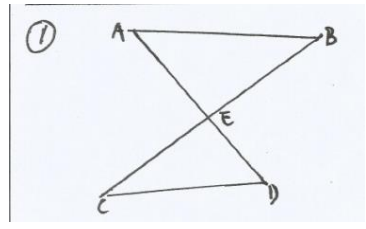

Diberikan : $\overline{A D}$ dan $\overline{B C}$ saling membagi sama panjang

di $E$.

Buktikan : $\triangle A E B \cong \triangle D E C$ 
Bukti:

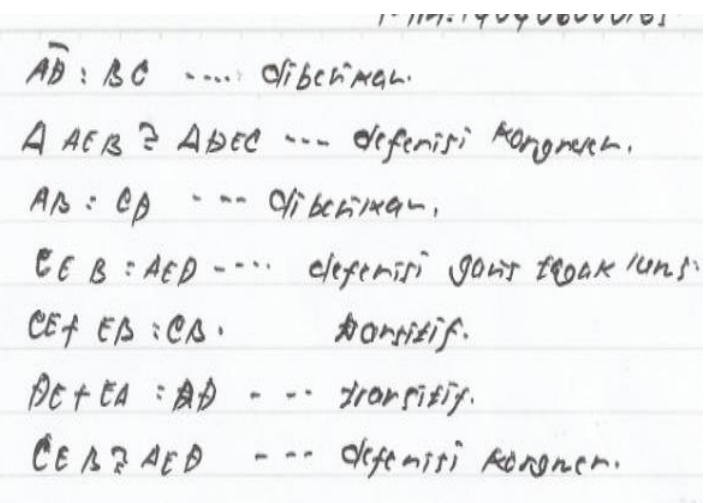

Gambar 2. Jawaban Mahasiswa

Dari jawaban di atas terlihat bahwa mahasiswa tidak mampu melihat sifat analitik dari kondisi yang diberikan dan menggunakan aturan untuk membuat rantai implikasi sehingga mencapai kesimpulan yang diinginkan.

Berdasarkan penelitian terdahulu tentang bukti, pentingnya berpikir analitik dalam mengonstruksi bukti serta fakta empiris di atas maka penelitian yang mengeksplorasi berpikir analitik mahasiswa dalam mengonstruksi bukti kongruensi segitiga secara sintaksis ini penting dilakukan. Penelitian ini dapat memberikan sumbangan teori mengenai berpikir analitik mahasiswa dalam mengonstruksi bukti secara sintaksis dan dapat digunakan dosen sebagai informasi mengenai berpikir analitik yang dapat dilakukan mahasiswa dalam mengonstruksi bukti secara sintaksis sehingga dosen dapat memilih metode pembuktian dalam mengajar yang disesuaikan dengan kemungkinan berpikir mahasiswa.

\section{METODE}

Penelitian kualitatif dengan jenis penelitian deskriptif eksploratif ini mengambil subjek dari sekelompok mahasiswa yang telah menempuh Geometri, karena tujuan dari penelitian ini adalah untuk mengetahui berpikir analitik yang melibatkan pengetahuan yang sudah tersimpan dalam memori. Berpikir analitik dalam mengonstruksi bukti secara sintaksis dilihat berdasarkan keanalitikan jawaban tertulis mahasiswa dan dipertegas dengan wawancara. Masalah pembuktian berupa masalah uraian yang diambil dari buku Geometry $A$ Contemporary Course oleh Harry Lewis.

Masalah tersebut dipilih karena memberikan kondisi awal tanpa suatu ukuran tertentu sehingga mahasiswa harus menyelesaikannya secara analitik. Selain itu gambar yang diberikan terdiri dari berbagai segitiga yang menuntut mahasiswa untuk dapat memilih segitiga segitiga tertentu sebagai kunci utama dalam pembuktian. Oleh karena itu masalah ini sesuai untuk digunakan karena penyelesaian secara analitik perlu didukung oleh berpikir yang analitik (Parta, 2016). Berikut ini adalah masalah yang digunakan dan struktur berpikir analitik yang diharapkan.

Diberikan : 


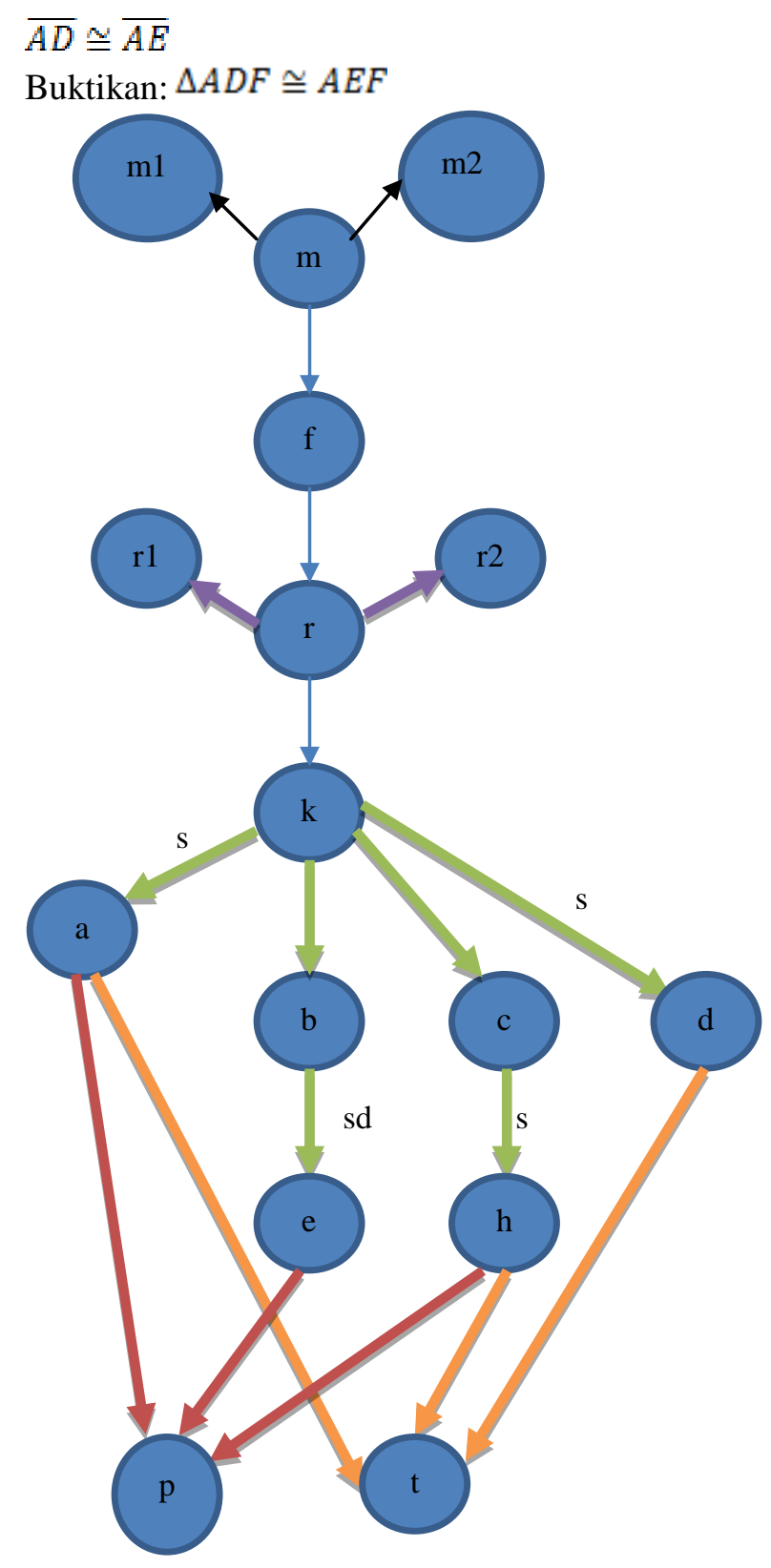

\begin{tabular}{|c|c|}
\hline Kode & Penjelasan \\
\hline $\mathrm{m}$ & Memahami masalah \\
\hline $\mathrm{m} 1$ & $\begin{array}{l}\text { Memahami yang } \\
\text { ditanyakan }\end{array}$ \\
\hline $\mathrm{m} 2$ & $\begin{array}{l}\text { Memahami asumsi dan } \\
\text { gambar yang diberikan }\end{array}$ \\
\hline$f$ & $\begin{array}{l}\text { Fokus pada } \\
\triangle A D F \text { dan } \triangle A E F\end{array}$ \\
\hline $\mathrm{r}$ & Menyusun rencana \\
\hline r1 & $\begin{array}{l}\text { Menggunakan teorema sisi, } \\
\text { sisi, sisi }\end{array}$ \\
\hline $\mathrm{r} 2$ & $\begin{array}{l}\text { Menggunakan postulat sisi, } \\
\text { sudut, sisi }\end{array}$ \\
\hline $\mathrm{k}$ & Melaksanakan rencana \\
\hline $\mathrm{a}$ & $\overline{A D} \cong \overline{A E}$ dari asumsi \\
\hline $\mathrm{b}$ & $\begin{array}{l}\text { Membuktikan } \\
\triangle A B E \cong \triangle A C D\end{array}$ \\
\hline c & $\begin{array}{l}\text { Membuktikan } \\
\triangle D B F \cong \triangle E C F\end{array}$ \\
\hline $\mathrm{d}$ & $\overline{A F} \cong \overline{A F}$ \\
\hline $\mathrm{e}$ & $\angle A D F \cong \angle A E F$ \\
\hline $\mathrm{h}$ & $\overline{D F} \cong \overline{E F}$ \\
\hline $\mathrm{p}$ & $\begin{array}{l}\triangle A D F \cong \triangle A E F \text { dengan } \\
\text { postulat sisi, sudut, sisi }\end{array}$ \\
\hline $\mathrm{t}$ & $\begin{array}{l}\triangle A D F \cong \triangle A E F \text { dengan } \\
\text { teorema sisi, sisi, sisi }\end{array}$ \\
\hline $\mathrm{s}$ & sisi \\
\hline sd & sudut \\
\hline$\Longrightarrow$ & Langkah selanjutnya \\
\hline$\longrightarrow$ & Postulat sisi, sudut, sisi \\
\hline$\longrightarrow$ & Teorema sisi, sisi, sisi \\
\hline$\longrightarrow$ & Memahami masalah \\
\hline$\longrightarrow$ & Melaksanakan rencana \\
\hline$\longrightarrow$ & merencanakan \\
\hline
\end{tabular}

Gambar 2. Struktur Berpikir

Format bukti yang diharapkan pada penelitian ini adalah format bukti dua kolom. Kolom yang kiri diisi oleh pernyataan dan di kolom yang kanan berisi alasan yang menjelaskan pernyataan tersebut, dimana pernyataan-pernyatan tersebut membentuk suatu argumen matematis yang mengarah pada suatu kesimpulan (Leff, 2009).

\section{HASIL}

Berpikir analitik dalam mengonstruksi bukti secara sintaksis terlihat sejak awal ketika subjek memilah dan memilih segitiga yang dianggap penting. Fakta ini sesuai dengan pengertian berpikir analitik menurut Amer, dkk (2005) yaitu kemamampuan untuk meneliti dan mengurai fakta-fakta dan pemikiran menjadi kekuatan-kelemahan. Bagian-bagian tersebut pada gambar 3 ditandai dengan 1, 2, 3 dimana keseluruhan dari bagian-bagian itu 
juga menunjukan konstruksi bukti secara utuh yang dibuat subjek. Subjek merencanakan pembuktian bertahap sesuai urutan tersebut. Berikut ini disajikan sketsa yang dibuat subjek.
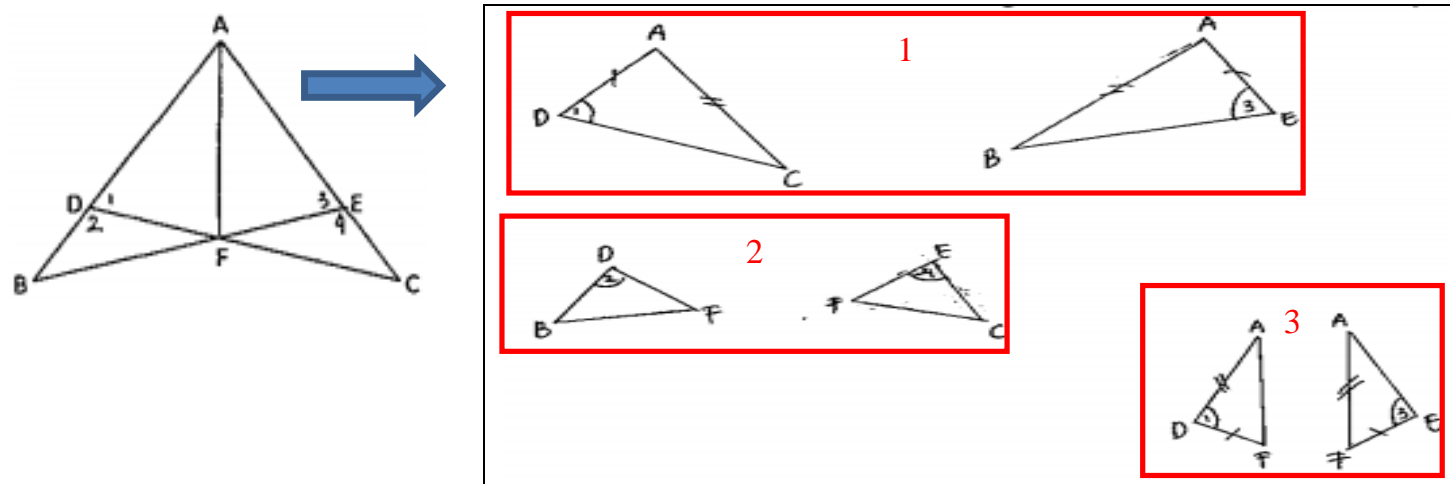

Gambar 3. Konstruksi Bukti

Berdasarkan konstruksi bukti yang telah dimiliki, subjek mengawali pembuktian dengan membuktikan $\triangle A B E \cong \triangle A C D$. Dengan memperhatikan kondisi awal yang diberikan dan memilih postulat yang dapat menghubungkan kondisi tersebut, maka subjek memutuskan menggunakan postulat sisi, sudut, sisi untuk membuktikan $\triangle A B E \cong \triangle A C D$. Kondisi ini sesuai dengan karakteristik berpikir analitik yang dinyatakan Kinard, James T., Alex Kozulin (dalam Parta, 2016), yaitu subjek menemukan prinsip dasar yang berlaku dalam penyelesaian tugas. Proses pembuktian ini dapat dilihat pada sub bukti 1 di bawah ini.

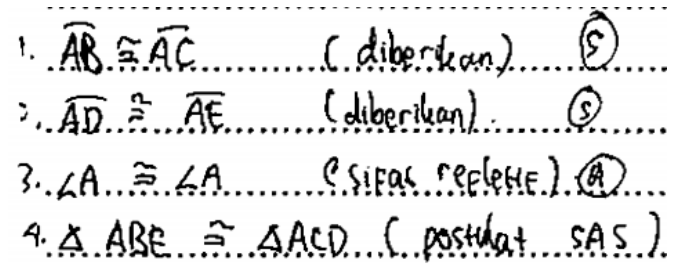

Gambar 4. Sub Bukti 1

Berikutnya berdasarkan konstruksi bukti subjek menyusun sub bukti 2 yang bertujuan untuk membuktikan $\triangle B D F \cong \triangle C E F$. Dengan mempertimbangkan sub bukti 1 dan fakta-fakta yang ada, subjek memutuskan menggunakan postulat sudut, sisi, sudut. Sub bukti

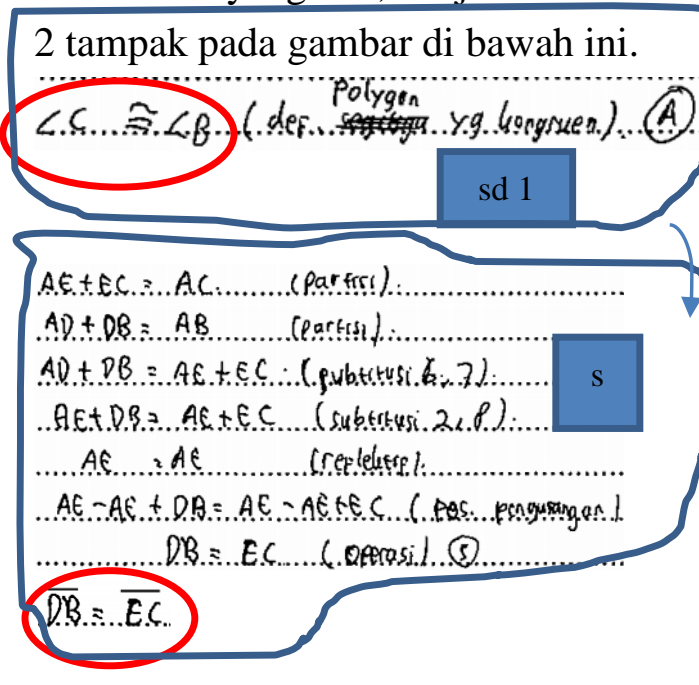

Gambar 5. Sub Bukti 2 
Pembuktian $\triangle B D F \cong \triangle C E F$ tampak pada empat bagian pada gambar di atas. Pertama subjek menyatakan bahwa $\angle B \cong \angle C$ pada gambar yang ditandai dengan sd 1 di atas berdasarkan definisi poligon yang kongruen yaitu $\triangle A B E \cong \triangle A C D$ yang diperoleh pada sub bukti 1. Berikutnya pada gambar yang ditandai $\mathrm{s}$ di atas, subjek menyatakan bahwa $A E+E C=A C$ dan $A D+D B=A B$ dengan alasan postulat partisi. Selanjutnya dengan alasan postulat substitusi subjek menyatakan bahwa $A D+D B=A E+E C$ karena berdasarkan kondisi yang diberikan $A C=A B$. Karena $A D=A E$ maka subjek mensubstitusi $A D$ dengan $A E$ dari langkah sebelumnya sehingga mengakibatkan $A E+D B=A E+E C$. Kemudian dengan alasan sifat refleksif subjek menyatakan bahwa $A E=A E$ dan berdasarkan postulat pengurangan subjek menyatakan bahwa $A E-A E+D B=A E-A E+E C$ sehingga akibatnya $D B=E C$ yang ekuivalen dengan $\overline{D B} \cong \overline{E C}$.

Tahap selanjutnya yang dilakukan subjek ditandai dengan sd 2 pada gambar di atas. Subjek menyatakan bahwa $\angle A E B \cong \angle A D C$ berdasarkan definisi poligon yang kongruen yaitu $\triangle A B E \cong \triangle A C D$. Kemudian subjek menyatakan bahwa $\angle A E B$ bersuplemen dengan $\angle B E C$ dan $\angle A D C$ bersuplemen dengan $\angle C D B$. Pernyataan subjek ini didasarkan pada sifat analitik dari sudut yang terbentuk dari dua sinar garis yang berlawanan. Dua sinar garis yang berlawanan adalah dua sinar yang mempunyai titik pangkal yang sama dan terletak pada garis yang sama tetapi arahnya berlawanan (Lewis, 1968). Dalam hal ini subjek memperoleh ide kunci yaitu sudut lurus. Dari definisi sudut lurus yaitu sudut yang ukurannya $180^{\circ}$ kemudian subjek menurunkan pernyataan-pernyataan yang dilandasi dengan definisi dua sudut bersuplemen yang jumlah ukurannya $180^{\circ}$. Kemudian subjek menyatakan bahwa $\angle B E C \cong \angle C D B$ berdasarkan teorema yang menyatakan jika dua sudut bersuplemen pada dua sudut yang kongruen maka dua sudut itu kongruen (Lewis, 1968).

Terakhir pada gambar 5 yang ditandai dengan sd, s, sd subjek menyimpulkan bahwa $\triangle B D F \cong \triangle C E F$ berdasarkan postulat sudut, sisi, sudut. Akibat dari $\triangle B D F \cong \triangle C E F$ adalah $\overline{E F} \cong \overline{D F}$. Setelah menyusun sub bukti 1 dan sub bukti 2 , subjek mengorganisir informasiinformasi penting untuk mencapai kesimpulan akhir. Fakta ini sesuai dengan pandangan Ferdinando, A. (dalam Parta, 2016) terhadap kegunaan berpikir analitik yaitu untuk mengorganisasikan informasi yang akan diartikulasikan. Hal tersebut tampak pada gambar di bawah ini.

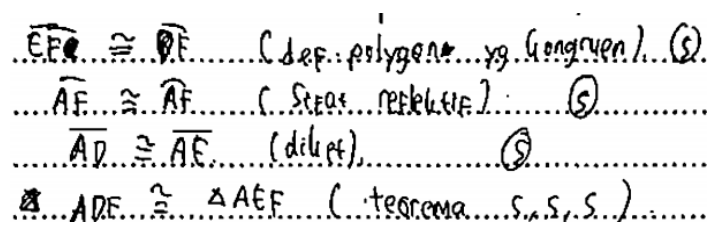

Gambar 6. Kesimpulan

Subjek menyatakan $\overline{E F} \cong \overline{D F}$ (sisi), $\overline{A F} \cong \overline{A F}$ (sisi) berdasarkan sifat refleksif kongruensi dan $\overline{A D} \cong \overline{A E}$ (sisi) dari kondisi yang diberikan. Sehingga dengan teorema sisi, sisi, sisi maka $\triangle A D F \cong \triangle A E F$. Jika dilihat secara utuh langkah-langkah subjek ini efektif, artinya untuk mencapai kesimpulan, subjek tidak melakukan langkah berlebih. 
Temuan lain pada penelitian ini adalah adanya berpikir semi analitik. Berpikir semi analitik ditandai oleh adanya "elemen-elemen" pengganggu yang mengakibatkan terputusnya struktur "logis" penyelesaian masalah (Parta, 2016). Pada langkah-langkah awal subjek mampu menyusun sub bukti secara analitik seperti di bawah ini.

1. $A B \cong=$ diketahut
$2 . \angle A=\angle A$
$3 . A D \cong \cong \overline{A E}$
$4 . \triangle A D C \cong \triangle A E B$

Gambar 7. Pekerjaan Awal

Beriktnya pada langkah 5 sampai langkah 11, subjek merujuk pada postulat partisi, postulat substitusi, sifat refleksif kongruensi dan postulat pengurangan. Namun pernyataan yang dilandasi oleh postulat substitusi tidak dinyatakan dengan simbol yang tepat. Hal tersebut tampak pada langkah 6 dan langkah 8 yaitu $\overline{A C}=\overline{A E}+\overline{B D}$ dan $\overline{A E}+\overline{B D}=\overline{A E}+\overline{E C}$. Substitusi hanya dapat dilakukan pada kuantitas, namun subjek mensubstitusi ruas garis dan bukan ukuran ruas garisnya. Begitupun pada langkah 10 subjek melakukan operasi pengurangan pada ruas garis dan bukan pada ukuran ruas garisnya. Adanya elemen-elemen inilah yang memutus rantai implikasi subjek yang berpikir semi analitik dan akibatnya bukti yang dihasilkan tidak valid.

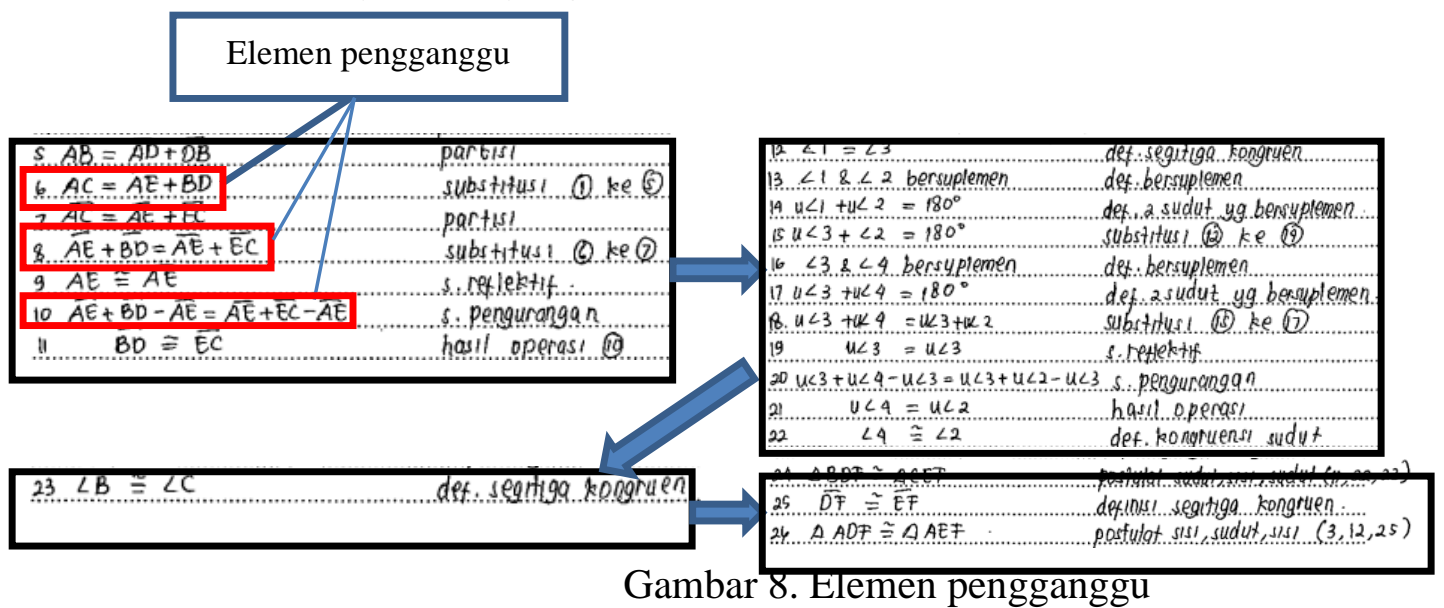

Temuan berikutnya adalah adanya berpikir pre analitik dalam mengonstruksi bukti secara sintaksis. Berpikir pre analitik subjek ditandai dengan penggunaan informasi permukaan (berupa gambar). Dalam matematika formal, gambar bukan penyelesaian final dari suatu masalah. Gamabar atau sketsa grafik digunakan hanya untuk identifikasi awal tentang kemungkinan model matematika atau strategi penyelesaian masalah yang sesuai (Parta, 2016). Dalam temuan ini sebujek mendemonstrasikan bukti dengan gambar dengan membuat ukuran tertentu dari ruas garis. Pekerjaan subjek tampak pada gambar di bawah ini.

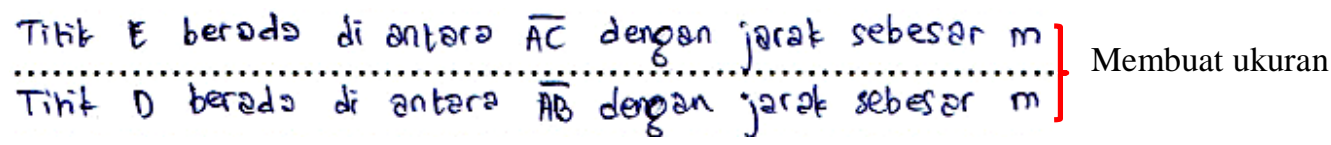




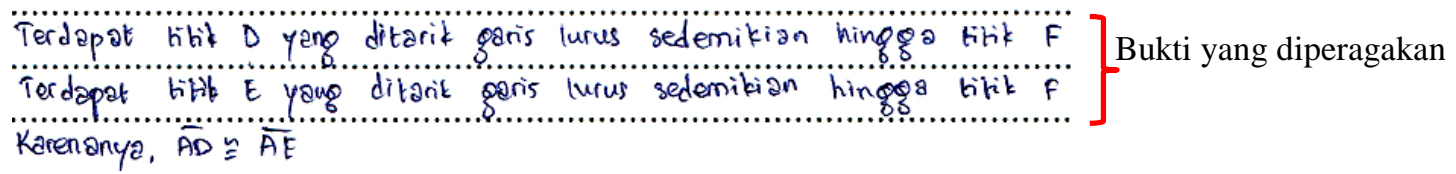

(b)

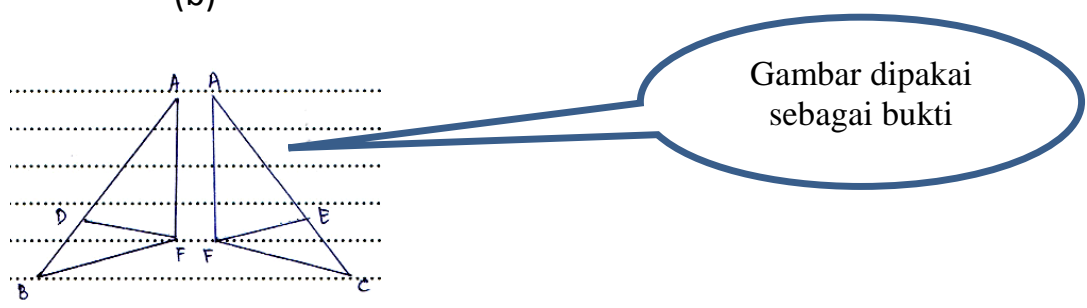

(c)

\section{PEMBAHASAN}

Berpikir yang termasuk jenis berpikir analitik yang dinyatakan oleh Stenberg, R.J, dkk (dalam Parta, 2016) mencakup kemampuan menganalisis, membandingkan, dan mengevaluasi. Jika dilihat dari hal tersebut maka munculnya elemen-elemen pengganggu pada berpikir semi analitik disebabkan karena ketidakmampuan subjek dalam mengevaluasi. Hal tersebut tampak pada kesalahan dalam penulisan simbol yang tidak disadari subjek. Subjek mensubstitusikan ruas garis dan melakukan operasi pengurangan pada ruas garis, bukan pada ukurannya. Adanya kesalahan dalam penulisan simbol tersebut mengakibatkan terputusnya struktur logis dari bukti yang disusun subjek sehingga bukti yang dihasilkan tidak valid.

Zhang (dalam Parta, 2016) memberikan batasan pada berpikir analitik yang mencakup empat aspek, yaitu; (1) pemisahan objek dari konteksnya, (2) kecenderungan untuk fokus pada atribut tertentu, (3) penetapan kategori, dan (4) pemilihan pada penggunaan aturan. Jika ditinjau dari empat aspek tersebut, maka berpikir pre analitik terjadi karena subjek cenderung untuk fokus pada atribut tertentu. Hal tersebut tampak ketika subjek membuat ukuran tertentu dari ruas garis. Subjek berkeyakinan bahwa setiap ruas garis pasti dapat diukur atau dapat dibuat suatu ukuran dengan satuan tertentu. Sehingga jika sudah diketahui ukurannya maka subjek dapat menentukan apakah dua segitiga yang diminta pada masalah kongruen atau tidak. Dalam hal ini subjek tidak berpikir secara deduktif formal.

\section{SIMPULAN DAN SARAN}

Berpikir analitik subjek dalam mengonstruksi bukti secara sintaksis ditandai oleh beberapa indikator, yaitu adanya konstruksi bukti yang jelas, kejelasan algoritma, keruntutuan penalaran, penggunaan simbol secara tepat, setiap pernyataan dilandasi oleh alasan yang tepat, dan langkah yang efektif. adanya konstruksi bukti yang jelas terlihat dari sketsa yang dibuat subjek. Konstruksi tersebut menunjukan penalaran bertahap yang dilakukan subjek. Kejelasan algoritma maksudnya adalah pada setiap langkah secara jelas ditunjukan informasi yang akan dicari. Keruntutun penalaran maksudnya adalah terdapat 
hubungan logis dari langkah yang mendahului ke langkah selanjutnya. Langkah yang efektif maksudnya tidak ada langkah yang berlebih untuk mencapai kesimpulan.

Berpikir semi analitik ditandai oleh adanya "elemen pengganggu" pemutus rantai implikasi. Adanya elemen pengganggu tersebut terjadi karena subjek melakukan kesalahan dalam penggunaan simbol ukuran ruas garis. Berpikir pre analitik ditandai oleh penggunaan gambar sebagai bukti. Subjek memperagakan bukti dengan membuat ukuran tertentu dari ruas garis untuk menyimpulkan kongruensi segitiga. Bukti tidak diturunkan secara deduktif formal.

Pada penelitian ini ditemukan subjek yang berpikir pre analitik dalam mengonstruksi bukti. Berpikir pre analitik terjadi ketika subjek memperagakan bukti menggunakan gambar yang secara mutlak tidak diterima dalam bukti formal. Subjek penelitian ini adalah mahasiswa yang seharusnya sudah mampu berpikir formal deduktif, oleh karena itu perlu adanya metode pembelajaran tentang pembuktian yang disesuaikan dengan kemungkinan berpikir mahasiswa agar pengetahuan dan pengalaman belajar terinternalisasi dengan baik.

\section{DAFTAR RUJUKAN}

Alcock, L.Inglis, M. 2010. Visual Consideration In The Presentation Of Mathematical Proofs. International Journal of Media, Technology and Lifelong Learning, 6 (1): 43 59.

Amer, Ayman, dkk. 2005. Analytical Thinking. Cairo: Center for Advancement Studies and Research in Engineering Science, Cairo: Faculty of EngineeringCairo University.

Chen,Y. 2008. From formal proofs to informal proofs-teaching. International Journal of Case Method Research \& Application. New Britain, Connecticut, U.S.A. : Central Connecticut State University.

Hanna, G., \& Barbeau, E. 2008. Proofs as bearers of mathematical knowledge. Zentralblatt für Didaktik der Mathematik, 40(30), 345-353.

Healy, L. \& Holyes, C. 1998. A study of proof conceptions in algebra. Journal for research in mathematics education, 31 (4) : $396-428$.

Leff, L., S. 2009. E-Z Geometry. New York: Barron's Educational Series.

Lewis, H. 1968 Geometry A Contemporary Course. New York: D. Van Nostand Company, Ltd.

Montaku, S., dkk. 2012. The Model Of Analytical Thinking Skill Training Process. Research Journal of Applied Sciences 7 (1) 17-20, 2012 ISSN: 1815-932X. Medwell Journal.

Montaku, S.. 2011. Results of Analytical Thinking Training Through Students in System Analysis and Design Course. Proceeding of the IETEC'11Conference, Kuala Lumpur, Malaysia.

Mulyati, S. 1999. Segitiga dalam Geometri. Malang: Departemen Pendidikan dan Kebudayaan Universitas Negeri Malang.

Musser, G.L. \& Burger, W.F. 1994. Mathematics for Elementary Teachers; A Contemporary Approach, third edition. New York; Mac Millan Publishing Company, Inc.

NCTM. 2000. Principles and Standards for School Mathematics. United States of America: The National Council of Teachers of Mathematics, Inc.

Orton, A. 1992. Learning Mathematics: Issue, Theory and Classroom Practice. London: Cassel.

Parta, I. N. 2016. Karakteristik Berpikir analitik Mahasiswa dalam Menyelesaikan "Masalah Sederhana”. Malang: Universitas Negeri Malang. 
Pinto, MMF. 1998. Students' Understanding of Real Analysis. Unpublished PhD Thesis. Warwick, UK: University of Warwick.

Recio, A.M. \& Godino, J.D. 2001. Institutional and Personal Meanings of Mathematical Proof. Educational Studies in Mathematics, Volume 48: 83-99.

Robbins, J. K. 2011. Problem solving, Reasoning, andAnalytical Thinking in a Classroom Environmen. Jurnal ISSN: 1555-7855 Vol. 12, No.1, page 40-47. Morningside Academy and Patnerships for EducationalExcellence and Research, International.

Ruseffendi, E.T. 1980. Pendidikan Matematika 3. Jakarta: Depdikbud.

Shelden, A. J. \& Selden. 2003. Validation of Proof Consideren as Texts: Can Undergraduates Tell Wether an Argument Proves a Theorem? Journal for Research Mathematics Education, 34(1):4-36.

Stylianou, D.A., Blanton, M. L., Knuth, E. J. 2009. Teaching and Learning Proof Across the Grades. New York: Routledge.

Tall, D.O. 2009. Cognitive and Social Development of Proof Through Embodiment, Symbolism \& Formalism. Dalam Lin, Fou Lai (eds). Proceeding of The ICMI Study 19 Conference: Proof and Proving in Math-ematics Education, Vol 2. Taipei: The Department of Mathematics, National Taiwan Normal University.

Varghese, T. 2009. Secondary-level Student Teachers' Conceptions of Mathematical Proof. Issues in the undergraduate Mathematics Preparation of School Teacher: The Journal, 1: $1-14$

Weber, K. 2001. Student Difficulty in Constructing Proofs: The Need for Strategic Knowledge. Educational Studies in Mathematics, Volume 48: 101-119.

Weber, K. 2004. A Framework for Describing the Processes That Undergraduates Use to Construct Proofs. Proceedings of the 28th Conference of the International Group for the Psychology of Mathematics Education, Vol 4 pp 425-432.

Weber, K., \& Alcock, L. (2004) Semantic and syntactic proof productions. Educational Studies in Mathematics, 56, 209-234.

Windsor W.J.J., M.Ed. 2008. Algebraic Thinking- More to Do with Why, Than $X$ and $Y$. Queensland: Griffith University.

Zazkis, R., Gholamazad, S., \& Liljedahl, P.. 2003. One Line Proof: What Can Go Wrong?. Proceeding of the $27^{\text {th }}$ Conference of The International Group for the Psychology of Mathematics Education, 2, 437 - 444. Honolulu, HI. 